\title{
HIV-1 Tat enhances purinergic P2Y4 receptor signaling to mediate inflammatory cytokine production and neuronal damage via PI3K/Akt and ERK MAPK pathways
}

Feng Zhou ${ }^{1,2,3^{*}} \mathbb{D}$, Xiaomei $\mathrm{Liu}^{2+}$, Lin $\mathrm{GaO}^{2+}$, Xinxin Zhou ${ }^{4+}$, Qianwen $\mathrm{CaO}^{2}$, Liping Niu², Jing Wang ${ }^{2}$, Dongjiao Zuo ${ }^{2}$, Xiangyang Li ${ }^{2}$, Ying Yang ${ }^{2}$, Minmin $\mathrm{Hu}^{2}$, Yinghua $\mathrm{Yu}^{2}$, Renxian Tang ${ }^{2}$, Bong Ho Lee ${ }^{4}$, Byoung Wook Choi ${ }^{4}$, Yugang Wang ${ }^{2}$, Yoshihiro Izumiya ${ }^{5}$, Min Xue ${ }^{6}$, Kuiyang Zheng ${ }^{2}$ and Dianshuai Gao ${ }^{3 *}$

\begin{abstract}
Background: HIV-associated neurocognitive disorders (HANDs) afflict more than half of HIV-1-positive individuals. The transactivator of transcription (Tat) produced by HIV virus elicits inflammatory process and is a major neurotoxic mediator that induce neuron damage during HAND pathogenesis. Activated astrocytes are important cells involved in neuroinflammation and neuronal damage. Purinergic receptors expressed in astrocytes participate in a positive feedback loop in virus-induced neurotoxicity. Here, we investigated that whether P2Y4R, a P2Y receptor subtype, that expressed in astrocyte participates in Tat-induced neuronal death in vitro and in vivo.

Methods: Soluble Tat protein was performed to determine the expression of P2Y4R and proinflammatory cytokines in astrocytes using siRNA technique via real-time PCR, Western blot, and immunofluorescence assays. Cytometric bead array was used to measure proinflammatory cytokine release. The TUNEL staining and MTT cell viability assay were analyzed for HT22 cell apoptosis and viability, and the ApopTag ${ }^{\circledR}$ peroxidase in situ apoptosis detection kit and cresyl violet staining for apoptosis and death of hippocampal neuron in vivo.

Results: We found that Tat challenge increased the expression of P2Y4R in astrocytes. P2Y4R signaling in astrocytes was involved in Tat-induced inflammatory cytokine production via PI3K/Akt- and ERK1/2-dependent pathways. Knockdown of P2Y4R expression significantly reduced inflammatory cytokine production and relieved Tat-mediated neuronal apoptosis in vitro. Furthermore, in vivo challenged with Tat, P2Y4R knockdown mice showed decreased inflammation and neuronal damage, especially in hippocampal CA1 region.
\end{abstract}

Conclusions: Our data provide novel insights into astrocyte-mediated neuron damage during HIV-1 infection and suggest a potential therapeutic target for HANDs.

Keywords: HIV-associated neurocognitive disorders, Astrocytes, Inflammatory cytokines, Purinergic P2Y4 receptor, Tat

\footnotetext{
* Correspondence: zhoufeng-xzmc@163.com; gds@xzhmu.edu.cn

†Feng Zhou, Xiaomei Liu, Lin Gao, and Xinxin Zhou contributed equally to this work.

${ }^{1}$ Jiangsu Key Laboratory of Brain Disease Bioinformation, Research Center for Biochemistry and Molecular Biology, Xuzhou Medical University, Xuzhou, Jiangsu 221004, People's Republic of China

${ }^{3}$ Xuzhou Key Laboratory of Neurobiology, Department of Neurobiology and

Anatomy, Xuzhou Medical University, Xuzhou 221004, Jiangsu, China

Full list of author information is available at the end of the article
}

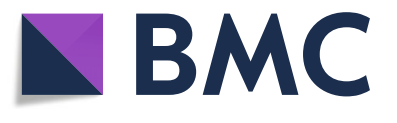

(อ) The Author(s). 2019 Open Access This article is distributed under the terms of the Creative Commons Attribution 4.0 International License (http://creativecommons.org/licenses/by/4.0/), which permits unrestricted use, distribution, and reproduction in any medium, provided you give appropriate credit to the original author(s) and the source, provide a link to the Creative Commons license, and indicate if changes were made. The Creative Commons Public Domain Dedication waiver (http://creativecommons.org/publicdomain/zero/1.0/) applies to the data made available in this article, unless otherwise stated. 


\section{Background}

HIV-associated neurocognitive disorders (HAND) include asymptomatic neurocognitive impairment (ANI), mild neurocognitive disorder (MND), and HIV-associated dementia. Although highly active antiretroviral therapy (HAART) reduced viral loading and prolonged life-span of acquired immunodeficiency syndrome (AIDS) patients, the prevalence of HAND appears to be rising up to more than 50\% among human immunodeficiency virus type 1 (HIV-1)-positive individuals. HAND is characterized by degenerative damage and loss of neurons and ultimately develops into HIV-associated dementia (HAD) [1-4]. In the central nervous system (CNS), HIV-1 itself and HIV-1-encoded proteins including transactivator of transcription (Tat) enhance altered neuroinflammation and neurotoxicity in astrocytes and microglia, contributing to the neuron damage and loss in the process of HAND [5-8].

Reactive astrocytosis is an important feature in inflammatory environment during the pathology of HAND [5, 9, 10]. Astrocytes, the major glial cell type within the brain $[11,12]$, represent an important reservoir for the production of various mediators of inflammation, particularly in response to HIV-1 infection [13, 14]. Astrocytes support neuron function through promoting synaptic formation and plasticity, and architecture the formation of the blood-brain barrier (BBB) [10]. Additionally, activated astrocytes are able to interact with the peripheral immune system by recruiting leukocytes and monocytes into the CNS [15]. Meanwhile, astrocyte activation is associated with the pathogenesis of HAND characterized by an increased the production of pro-inflammatory cytokines and chemokines $[3,5]$. In response to HIV-1 or Tat, astrocytes elicit chemokines and chemokine production to promote the recruitment of $\mathrm{T}$ cells and monocytes into the brain [5]. HIV-infected monocytes and $\mathrm{T}$ cells not only infect brain resident cells but also release proinflammatory cytokines such as tumor necrosis factor (TNF) and interleukin-1 beta (IL-1 $\beta$ ), which further activates astrocytes [5]. Of important, these activated astrocytes are important contributors to neuroinflammation and release neurotoxic factors such as excitatory amino acids and adenosine $5^{\prime}$-triphosphate (ATP), resulting in neuronal dysfunction and death [16, 17].

Tat, a multifunctional protein of $86-101$ aa, is produced from HIV-1-infected cells and releases into the tissues and blood in HIV $-1^{+}$individuals. Meanwhile, Tat is secreted from resident CNS cells such as microglia and astrocytes into the CSF [18], and increases the production of soluble neurotoxic factors including inflammatory cytokines [5], which involved in the development and progression of HAND in $\mathrm{HIV}-1^{+}$patients [19-24]. Studies showed that Tat induced pro-inflammatory cytokines like interleukin-6 (IL-6), IL-8, and interferon-gamma-inducible 10-Kd protein (IP-10) in astrocytes, which involved nuclear factor-kappa B
(NF-kB), AP-1, C/EBP $\alpha$, and $\mathrm{C} / \mathrm{EBP} \gamma$ transcription factors and JAK, PI3K/Akt, and MAPK signaling pathways [2527]. In addition, some studies reported that Tat induced neurotoxic factors such as excitatory amino acids, ATP, and calcium overload, resulting in neuron death [28, 29]. Therefore, Tat protein treatment in mice can induce key aspects of HAND neurotoxicity [30].

Purinergic P2 receptor family includes P2Y1R, P2Y2R, P2Y4R, P2Y6R, P2Y12R, and P2Y14R that express in CNS astrocytes [31, 32]. Recent data have demonstrated that ATP is recognized to act through purinergic P2 receptors widely expressed in the brain [33], which are involved in glia-glia and glia-neuron communications [34], thus playing important physiological and pathophysiological roles in a variety of biological processes and neurodegenerative diseases [35]. Previous evidence has documented that a non-selective P2 receptor antagonist, PPADS, improves the morphological and functional alterations provoked by the ischemic injury [36]; A P2Y1 agonist, 2-MeSADP, significantly reduces cytotoxic edema and the magnitude of ischemic lesions [37]. Inhibition of P2Y1 receptors in astrocytes results in cytokine/chemokine transcriptional suppression, which involves the NF-kB pathway [38]. Moreover, PPADS confers neuroprotection against glutamate/NMDA toxicity [39]. Recent studies found that purinergic receptor P2Y6 contributes to 1-methyl-4-phenylpyridinium-induced oxidative stress and cell death [40]. PI3K/AKT and ERK MAPK pathways are involved in activating purinergic P2 receptor [41-43]. These results prompt us to determine purinergic P2 receptor signaling in astrocytes and their roles in HAND pathogenesis.

In the present study, we analyzed purinergic P2 receptor expression in astrocytes treated by soluble Tat protein. Our results found that Tat enhanced P2Y4R signaling to mediate inflammatory process that contributed to neuron apoptosis and death via PI3K/AKT- and ERK-dependent pathways. Furthermore, P2Y4R knockdown in mice significantly suppressed inflammatory cytokine production and relieved hippocampal CA1 neuron apoptosis in Tat-treated mice. These data support a role of $\mathrm{P} 2 \mathrm{Y} 4 \mathrm{R}$ in regulating neuroinflammation and neuron damage during the process of HAND.

\section{Methods \\ Animals}

C57BL/6 mice were purchased from Nanjing University Laboratory Animal Center. Mice were bred and maintained under specific pathogen-free conditions. All experimental procedures described in our study were carried out based on the Provision and General Recommendation of the Chinese Laboratory Association. The protocol was approved by the Institutional Animal Care and Use Committee of Xuzhou Medical University. 


\section{Reagents and antibodies}

Full-length recombinant Tat (1-101 aa, ab83353) was from Abcam. ATP (A1852), LY294002 (440202), and PD98059 (P215) were from Sigma-Aldrich. Multiplex magnetic bead-based antibody detection kits (cytokine and chemokine detection kits, Cytometric Bead Array) were purchased from BD Biosciences (560485, 558342). LV3-sh-NC and LV3-sh-mouse P2Y4R were purchased from GenePharma (Shanghai, China). TUNEL staining kit (11684817910) was from Roche. The ApopTag peroxidase in situ apoptosis detection kit (S7100) was purchased from Chemicon International, Inc. Anti-GFAP antibodies (ab4648 and MAB360) were from Abcam and Millipore. Anti-P2Y4R antibody (APR-006) was from Alomone labs. Anti-p-AKT (Ser473, 4060) and anti-p-ERK1/2 (Thr202/ Thr204, 5726) antibodies were from Cell Signaling Biotechnology. Anti-Bcl-2 (sc-509) antibody, anti-Bax (sc-20067) antibody, anti- $\beta$-Actin (sc-47778), and anti-Tubulin antibodies were purchased from Santa Cruz Biotechnology. Alexa Fluor 488 donkey anti-mouse IgG (A21202) and Alexa Fluor 594 donkey anti-mouse IgG (A21207) antibodies were from Life technologies. The secondary antibodies of goat anti-mouse IgG and goat anti-rabbit IgG were purchased from Santa Cruz Biotechnology.

\section{Cell culture}

Isolation and culture of primary mouse astrocytes from 0- to 1-day-old C57BL/6 mice were established as previously described [44-46]. Briefly, the cerebral cortices freed of meninges were dissected, minced, and digested. The cells were filtrated, transferred to culture flasks pre-coated with $1 \mathrm{mg} / \mathrm{ml}$ poly-L-lysine (Sigma-Aldrich), and then cultured DMEM/F12 medium containing $10 \%$ fetal bovine serum (FBS). Cells were passed for three passages, and then detected glial fibrillary acidic protein (GFAP, astrocytic marker) expression through immunofluorescence assays (IFA). Finally, at least $95 \% \mathrm{GAFP}^{+}$cells were used to research.

Murine hippocampal neuron HT-22 cells and human glioma U261 cells were obtained from the Cell Bank of Chinese Academy of Science (Shanghai, China). HT-22 and U261 cells were cultured in DMEM supplemented with 10\% heat-inactivated FBS (fetal bovine serum), $50 \mathrm{U} / \mathrm{ml}$ penicillin and streptomycin (Sigma-Aldrich) under a humidified atmosphere containing $5 \% \mathrm{CO}_{2}$ at $37{ }^{\circ} \mathrm{C}$.

\section{RNA extraction, reverse transcription, and real-time PCR assay}

Total RNA was extracted from astrocytes and hippocampal tissues according to manufactures instructions. Reverse transcription and real-time PCR (qPCR) assay was performed as previously described [47]. The sequences of primers are listed in Additional file 1: Table S1.

\section{Western blotting analysis}

Total protein was extracted from mouse hippocampal tissues and from primary astrocytes as described previously [48]. The expression of protein in samples was normalized by $\beta$-actin or Tubulin.

\section{Immunofluorescence assay}

Protein expression was performed by the immunofluorescence assay (IFA) as previously described [49].

\section{Cytometric bead array}

The concentration of inflammatory cytokines was measured using a cytometric bead array (CBA; Multiplex magnetic bead-based antibody detection kits, BD Biosciences, CA, USA) as per manufacturer's instructions. Conditioned media samples from astrocytes were spun at $160 \times \mathrm{g}$ for $5 \mathrm{~min}$ and collected and stored at $-20{ }^{\circ} \mathrm{C}$. CBA samples were run on a FACSCanto ${ }^{\text {Tx }}$ II flow cytometer (BD Biosciences, CA, USA). Data were analyzed using the BD FACSDiva software and normalized as described previously $[46,50]$.

\section{MTT cell viability assay}

Cell viability was examined by MTT assays according to standard methods as previously described [48].

\section{ATP measurement}

ATP levels were measured using the ATPlite luminescence assay system (PerkinElmer, 6016943) according to the manufacturer's instructions [51].

\section{Lentivirus and Tat administration in mice}

To silence the mouse P2Y4R, shRNA sequences were designed. ShRNA sequences were as followed: sh-negative control, 5' -TTC TCC GAA CGT GTC ACG T-3'; sh-P2Y4R-1, 5' -CCU GUU GCC UCU GAG CUA UTT-3' and sh-P2Y4R-2, 5'-CCA CUU ACA UGU UCC AUU UTT-3'; sh-P2Y4R-3, 5'-CCT GTT GCC TCT GAG CAT T-3'. ShRNA sequences were cloned into the LV3-eGFP vector (GenePharma), and lentiviruses were packaged, which were named as LV-sh-Ctrl, LV-sh-P2Y4R1/2/3, respectively.

Then, $1 \times 10^{7} \mathrm{TU}$ (transduction unit) of LV-sh-Ctrl or LV-sh-P2Y4R were injected into 8-week-old C57BL/6 mice through the tail vein (Additional file 1: Figure S1), followed by Tat protein $(1 \mu \mathrm{g})$ in $2 \mu \mathrm{l}$ of PBS was administrated to mice through intracerebroventricular (i.c.v.) infusion site at $\mathrm{A} / \mathrm{P} 1.0 \mathrm{~mm}, \mathrm{~L} / \mathrm{M}$ $1.0 \mathrm{~mm}$, and $\mathrm{D} / \mathrm{V} 3.0 \mathrm{~mm}$ from the bregma, two times per week for 4 weeks 


\section{Histopathology}

Mice were anesthetized and perfusion-fixed with $4 \%$ paraformaldehyde. For measuring hippocampal neuron apoptosis, sections $(4 \mu \mathrm{m})$ from brain tissues were determined by the ApopTag peroxidase in situ apoptosis detection kit according to the manufacturer's protocol as previously described [52]. For evaluating hippocampal neuron death, the paraffin-embedded sections $(4 \mu \mathrm{m})$ from brain tissues were stained with cresyl violet and examined by light microscopy, and the pyramidal cell numbers of surviving in hippocampal CA1/1 $\mathrm{mm}$ of length were counted as neuron density [52].

\section{Statistical analysis}

Statistical analysis was performed using SPSS version 18.0 to analyze experimental data. Data presented as mean \pm standard error of mean (mean \pm S.E.M.). Statistical significance was determined by the two-tailed Student's $t$ test or one-way analysis of variance (ANOVA). $P<0.05$ was considered significant.

\section{Results}

HIV-1 Tat promotes P2Y4R expression in primary mouse astrocytes

To test whether purinergic P2Y receptors involve in Tat-induced astrocyte activation, we first determined P2YR expression after Tat stimulation. Primary mouse astrocytes were treated with $100 \mathrm{ng} / \mathrm{ml}$ of soluble full-length recombinant Tat protein in serum-free media; q-PCR assay were performed to measure the transcriptional levels of P2Y1R, P2Y2R, P2Y4R, P2Y6R, P2Y12R, and P2Y14R. As shown in Fig. 1a, the mRNA expression level of P2Y4R was dramatically increased starting at $3 \mathrm{~h}$, peaked at $12 \mathrm{~h}$, and remained high even after $24 \mathrm{~h}$ Tat stimulation. Besides P2Y2R mRNA level elevated only at $6 \mathrm{~h}$, the levels of expression of other P2Y receptors were not changed. To determine whether Tat promoted P2Y4R protein expression, immunoblotting and IFA were carried out. Western blotting results indicated that Tat induced P2Y4R expression (Fig. 1b, c), which was correlated with its mRNA expression. Moreover, IFA showed that P2Y4R expression was higher in Tat-treated astrocytes than that of negative

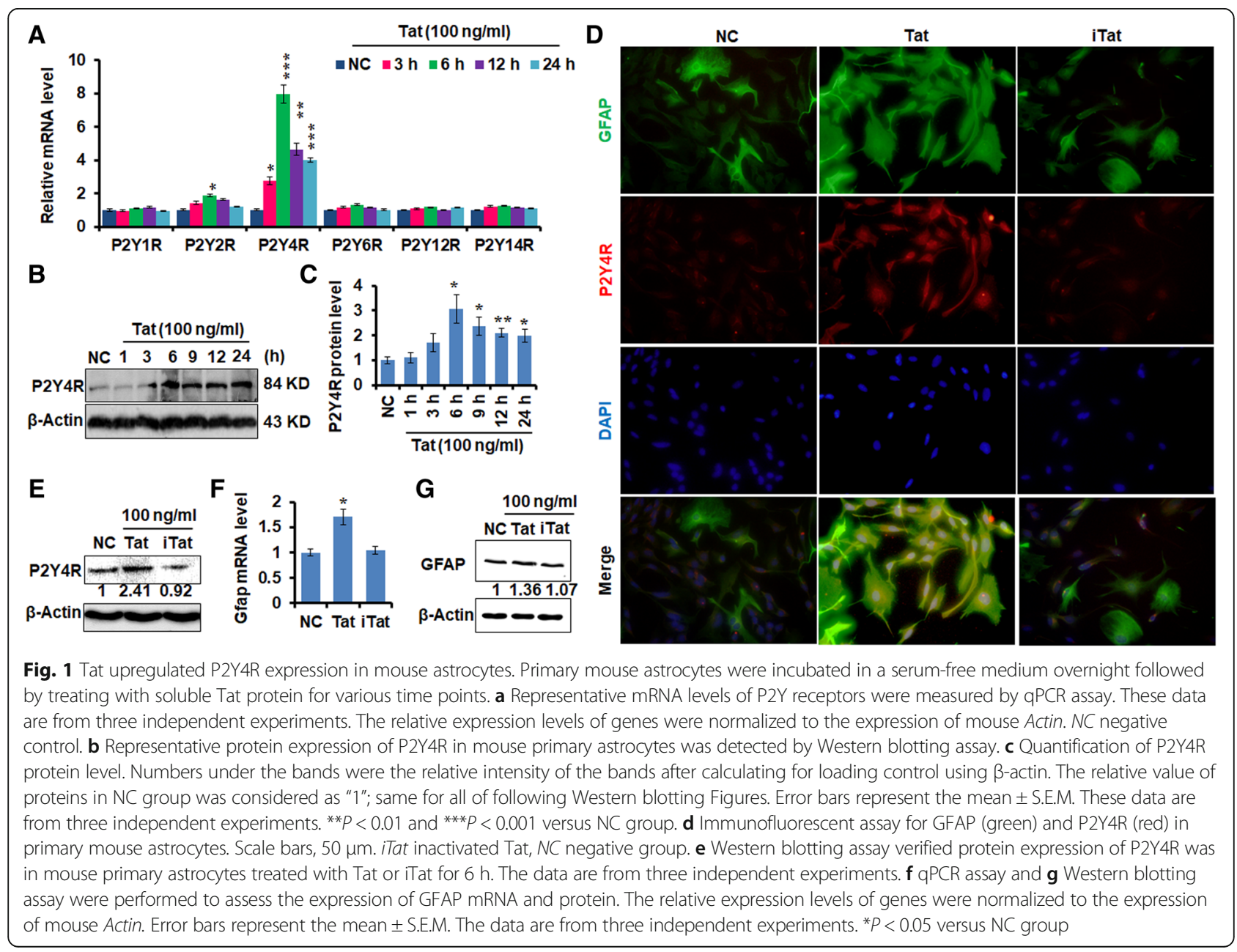


control (NC) group (Fig. 1d). To rule out Tat-unrelated effect, we heat-inactivated Tat (iTat) by incubating the recombinant Tat protein in $95{ }^{\circ} \mathrm{C}$ for $10 \mathrm{~min}$ before adding to primary astrocyte culture. IFA and Western blotting assay indicated that iTat could no longer induce P2Y4R expression (Fig. 1d, e). These results suggest that Tat enhances P2Y4R expression in astrocytes.
Multiple reports have suggested that HIV-1 Tat induces GFAP expression in astrocytes as a marker for tat-induced astrogliosis. As shown in Fig. 1d, Tat appeared to increase GFAP expression. To determine the role of GFAP induction by Tat, q-PCR and immunoblot assay were performed. The soluble Tat enhanced the level of GFAP mRNA and protein (Fig. 1f, g).
A

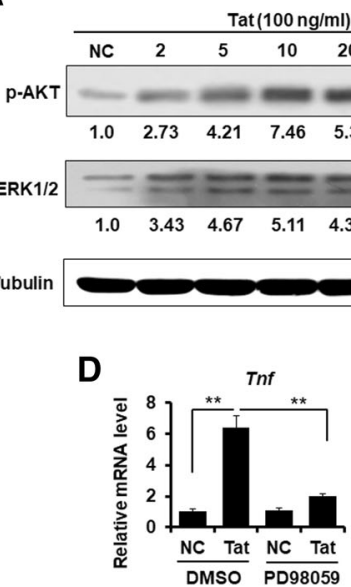

E

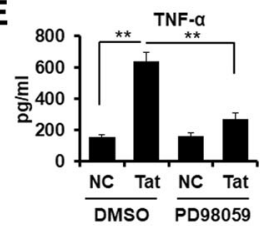

$\mathbf{F}$

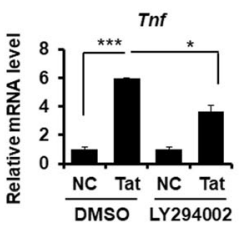

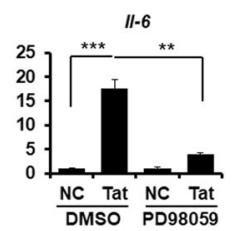
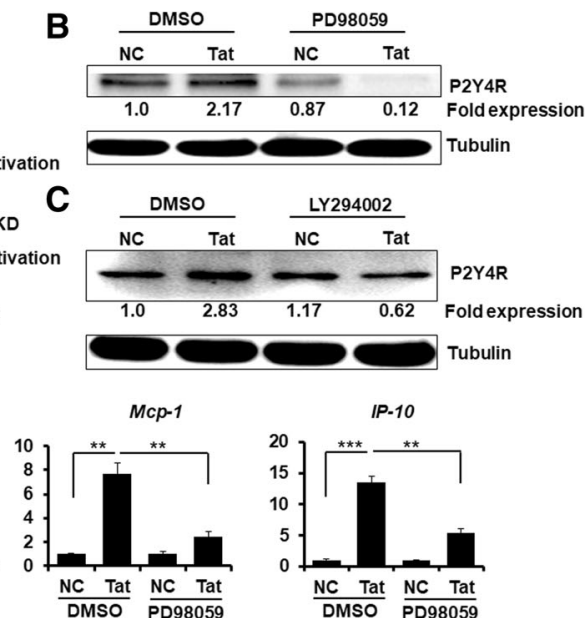

C
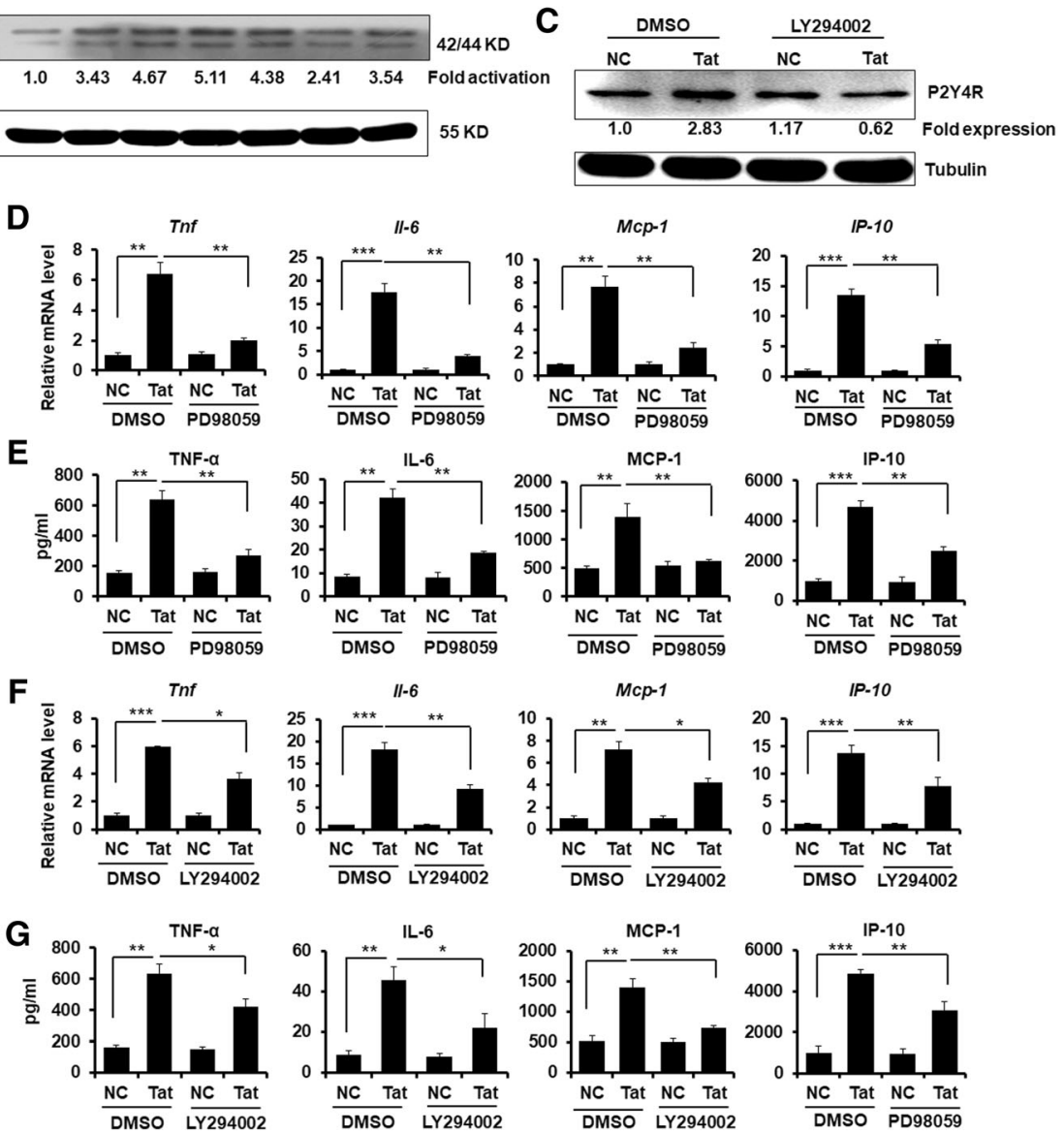

Fig. 2 PI3K Akt and ERK signal pathways were involved in Tat-induced P2Y4R expression and inflammatory response in mouse astrocytes. a Primary mouse astrocytes were incubated in a serum-free medium overnight followed by treating with soluble Tat protein for different time point. Representative levels of phosphorylation of Akt ( $p$-Akt) and p-ERK1/2 were displayed by Western blotting assay. These data are from three independent experiments. b, c Primary mouse astrocytes were incubated in a serum-free medium overnight followed by pretreating with or

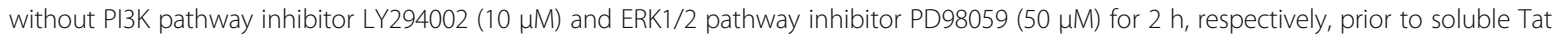
protein stimulus for $6 \mathrm{~h}$. Representative levels of P2Y4R protein were determined by Western blotting assay. These data are from three independent experiments. d, e Primary mouse astrocytes were incubated in a serum-free medium overnight followed by pretreating with or without 50 MM PD98059 for 2 h, prior to soluble Tat protein stimulus for 6 h. $\mathbf{d}$ Relative mRNA and e release levels of TNFa, IL-6, IP-10, and MCP1 were measured by qPCR assay and Cytometric Bead Array, respectively. The data are from three independent experiments. The relative expression levels of genes were normalized to the expression of mouse Actin. ${ }^{*} P<0.05,{ }^{* *} P<0.01$, and ${ }^{* * *} P<0.001$. f, $\mathbf{g}$ Primary mouse astrocytes were incubated in a serum-free medium overnight followed by pretreating with or without $10 \mu \mathrm{M}$ LY294002 for 2 h, prior to soluble Tat protein stimulus for 6 h. f Relative mRNA and $\mathbf{g}$ release levels of TNFa, IL-6, IP-10, and MCP-1were measured by qPCR assay and Cytometric Bead Array, respectively. These data are from three independent experiments. The relative expression levels of genes were normalized to the expression of mouse Actin. The data are represented as the mean \pm S.E.M. ${ }^{*} P<0.05$, ${ }^{* *} P<0.01$, and ${ }^{* * *} P<0.001$ 
Inhibition of PI3K/Akt and ERK MAPK pathways suppresses Tat-mediated P2Y4R expression and inflammatory response in the primary mouse astrocytes To further investigate potential molecular mechanisms by which Tat induces P2Y4R expression, we analyzed the phosphorylation levels of Akt and ERK1/2 in synchronized astrocytes stimulated with Tat protein at different time point. Phosphorylated Akt (p-Akt) was increased by 2.73 times, 4.21 times, 7.46 times, 5.33 times, 3.17 times, and 2.52 times in astrocytes treated with Tat at $2 \mathrm{~min}, 5 \mathrm{~min}, 10 \mathrm{~min}, 20 \mathrm{~min}$, and $30 \mathrm{~min}$, respectively (Fig. 2a). Similarly, the phosphorylation level of ERK1/2 (p-ERK1/2) was risen by 3.43 times, 4.67 times, 5.11 times, 4.38 times, 2.41 times, and 3.54 times in astrocytes treated with Tat at $2 \mathrm{~min}, 5 \mathrm{~min}, 10 \mathrm{~min}, 20 \mathrm{~min}$, and $30 \mathrm{~min}$, respectively (Fig. 2a). The data indicate that Tat activates Akt and ERK1/2 signal pathways.

Then, we assessed whether Akt and ERK1/2 signal pathways were essential in P2Y4R expression induction by Tat. The PI3K/Akt pathway inhibitor LY294002 and ERK1/2 inhibitor PD98059 were applied to primary mouse astrocytes, followed by Tat. Inhibition of both PI3K/Akt and ERK1/2 pathways reduced significantly P2Y4R protein expression (Fig. 2b, c). Thus, Tat triggers PI3K/Akt and ERK1/2 signal pathways to promote P2Y4R expression in astrocytes.

To investigate whether PI3K/Akt and ERK MAPK signals is also required for inflammatory cytokine production during Tat challenges, the levels of TNF $\alpha$, IL-6, IP-10, and monocyte chemoattractant protein-1 (MCP-1) were monitored. Both PD98059 and LY294002 dramatically reduced mRNA level of Tnfa, Il-6, IP-10, and $M c p-1$ as determined by qPCR in in primary mouse astrocytes stimulated by Tat (Fig. $2 \mathrm{~d}, \mathrm{f}$ ). The protein levels of TNF $\alpha$, IL-6, IP-10, and MCP-1 were also significantly diminished in astrocytes after pretreated by PD98059 and LY294002 (Fig. 2e, g).

\section{P2Y4R signaling regulates inflammatory response in} mouse astrocytes by Tat

To ascertain whether P2Y4R signal was involved in regulating Tat-induced inflammatory responses, P2Y 4R
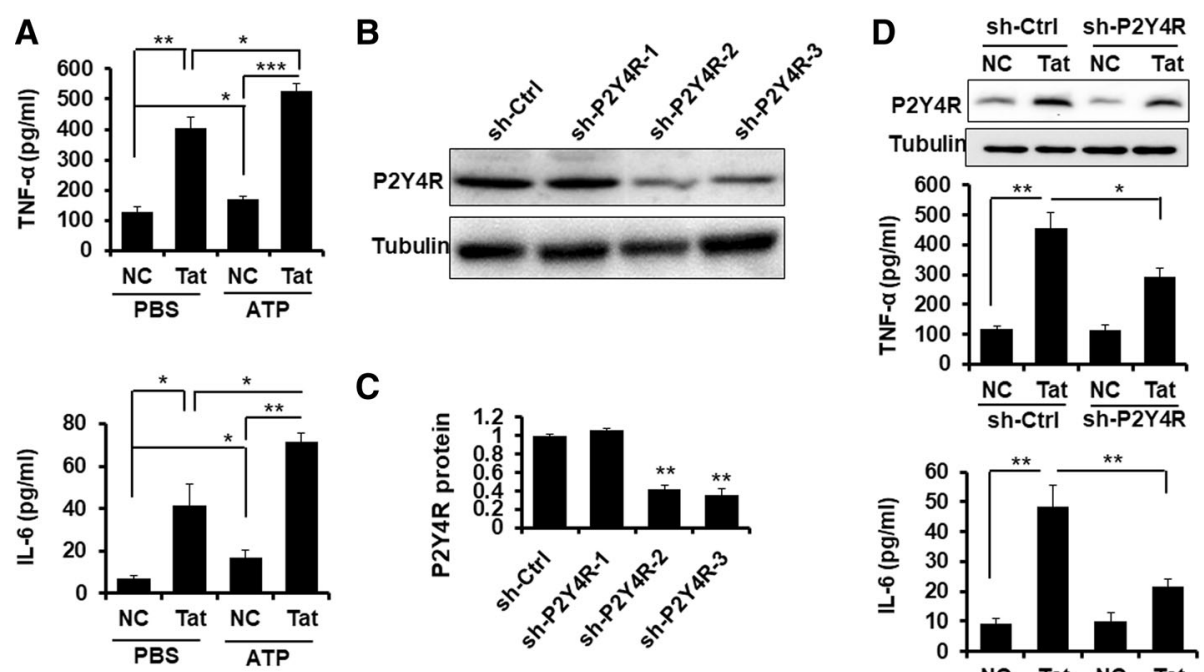

C
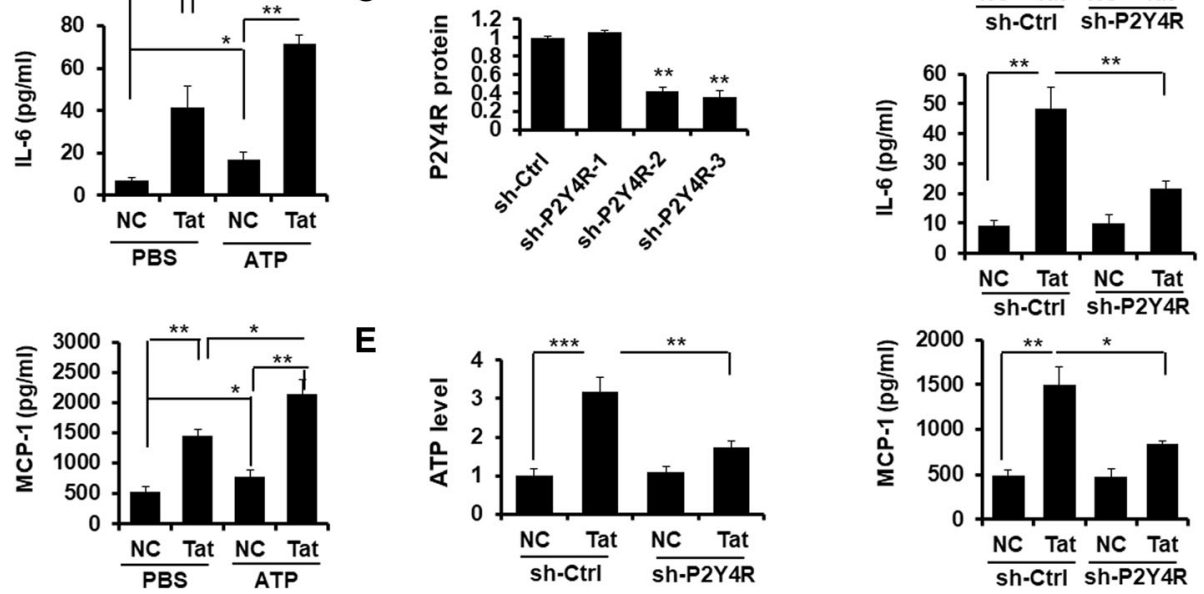

Fig. 3 P2Y4R signaling regulates inflammatory response and ATP production in mouse astrocytes by Tat. a Primary mouse astrocytes were incubated in a serum-free medium overnight followed by pretreating with or without $100 \mu \mathrm{M}$ ATP for $2 \mathrm{~h}$, prior to soluble Tat protein stimulus for $6 \mathrm{~h}$. Relative release levels of TNFa, IL-6, and MCP-1were determined by cytometric bead array. These data are from three independent experiments. Error bars represent the mean \pm S.E.M. ${ }^{*} P<0.05$, ${ }^{*} P<0.01$, and ${ }^{* *} P<0.001$. b, c Determination of sh-RNA knockdown of P2Y4R were performed by Western blotting assay in primary mouse astrocytes transduced with sh-Ctrl and sh-P2Y4R1/2/3 for $72 \mathrm{~h}$, respectively. ${ }^{* *} P<0.01$ versus NC. $\mathbf{d} P 2 Y 4 R$ protein was measured by immunoblotting assay, and relative protein levels of TNFa, IL-6, and MCP-1 were determined by cytometric bead array $(n=3)$. The data are represented as the mean \pm S.E.M. ${ }^{*} P<0.05$ and ${ }^{* *} P<0.01$. e Relative ATP levels were analyzed by the ATPlite luminescence assay system. The data are from three independent experiments. The data are represented as the mean \pm S.E.M. ${ }^{* *} P<0.05$ and ${ }^{* *} P<0.01$ 
agonist ATP was applied to primary mouse astrocytes together with or without soluble Tat protein. As shown in Fig. 3a, ATP significantly enhanced the effect of Tat-induced TNF $\alpha$, IL-6, and MCP-1 expression. To further demonstrate the role $\mathrm{P} 2 \mathrm{Y} 4 \mathrm{R}$ in Tat-mediated inflammation, P2Y4R expression was knockdown by shRNA. Sh-P2Y4R-3 significantly suppressed P2Y4R expression (Fig. 3b, c). We then treated the primary mouse astrocytes that had transduced by sh-P2Y4R-3 or sh-Ctrl with Tat for $24 \mathrm{~h}$; the secretion of TNFa, IL-6, and MCP-1 was measured by Cytometric Bead Array. Imminoblot assay confirmed that P2Y4R knockdown inhibited Tat-induced P2Y4R protein, and importantly P2Y4R knockdown decreased the release of TNF $\alpha$, IL-6, and MCP-1 significantly (Fig. 3d). Overall, these data confirm that P2Y4R signaling participates in Tat-induced proinflammatory cytokine production.

\section{P2Y4R inhibition decreases the release of ATP in mouse} astrocytes by Tat

To determine how Tat engages P2YR signals, ATP production were measured using the ATPlite luminescence assay system. The results indicated that ATP release was dramatically increased in astrocytes treated with Tat, and interestingly, it also significantly reduced in P2Y4R-3knockdowned cells (Fig. 3e).

Tat upregulates P2Y4R signaling to mediate inflammatory process and ATP release in human glioma cells via PI3K/ Akt and ERK pathways

To determine whether the Tat-induced P2Y4R pathway also works in human astrocyte, human glioma U251 cells were pretreated with or without PD98059 and LY294002 for $2 \mathrm{~h}$, followed by soluble Tat stimulus for another $6 \mathrm{~h}$, and PRY4R protein expression was then determined by immunoblot assay; the mRNA levels of $T N F \alpha, I L-6, M C P-1$, and ATP were detected by qPCR and ATPlite luminescence assay, respectively. Western blotting results indicated that P2Y4R expression was significantly enhanced by Tat, and was reduced by PD98059 or LY294002 (Fig. 4a). Tat-induced TNF $\alpha, I L-6$, and $M C P-1$ mRNA expression were dramatically suppressed by PD98059 and LY294002 (Fig. 4b). ATPlite luminescence assay showed that ATP levels were increased by Tat, and was decreased upon treatment with PD98059 or LY294002 (Fig. 4c). These data indicate that soluble Tat enhances P2Y4R signaling in human astrocytes via PI3K/Akt and ERK pathways.
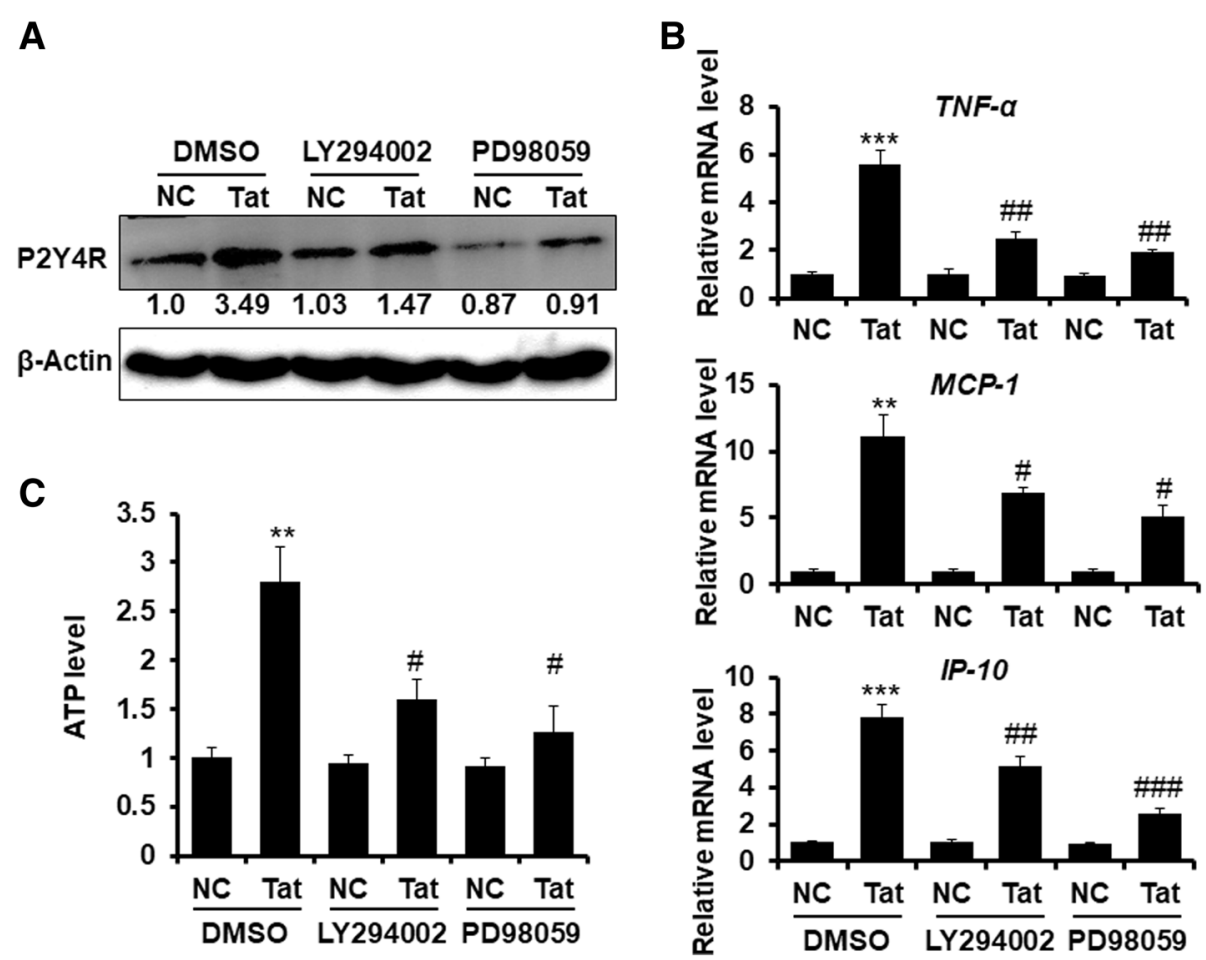

Fig. 4 Tat upregulates P2Y4R signaling to produce inflammatory cytokines and ATP release in human glioma cells via PI3K/AKT and ERK pathways. Human glioma U251 cells were pretreated with or without PD98059 and LY294002 for 2 h, followed by soluble Tat stimulus for 6 h. a PRY4R protein expression was determined by Western blotting assay. $\mathbf{b}$ The mRNA levels of TNFa, $L L-6, M C P-1$ were detected using qPCR. The relative expression levels of genes were normalized to the expression of human Actin. c ATP was detected using ATPlite luminescence assay system. The Data are from three independent experiments. The data are represented as the mean \pm S.E.M. ${ }^{* *} P<0.05$ and ${ }^{* * *} P<0.01$ versus NC with DMSO; ${ }^{\#} P<0.05$, ${ }^{\# \#} P<0.01$ and ${ }^{\# \# \# P} P .001$ versus Tat with DMSO 
P2Y4R knockdown displays neuroprotective effect against Tat

Previous data have documented that $\mathrm{P} 2$ receptors are associated with the growth and survival of neurons in the CNS [53]. To explore whether P2Y4R signal protected neuron injury against Tat, primary mouse astrocytes were transduced by LV-sh-P2Y4R-3 or LV-sh-Ctrl for $72 \mathrm{~h}$, followed by Tat stimulus for $24 \mathrm{~h}$, and then cell culture supernatants were collected as astrocyte-derived conditioned media (ACM). The ACM was applied to HT-22 cell, an immortalized mouse hippocampal cell. The apoptotic cell death and cell survival were determined by TUNEL staining and MTT cell viability assay, respectively. TUNEL staining showed that a large number of apoptotic cells were observed in LV-sh-Ctrl-treated group, but which was reversed in LV-sh-P2Y4R-treated group (Fig. 5a, b). Cell viability was decreased in the ACM derived from LV-sh-Ctrl-transduced astrocytes, which was rescued in the ACM from LV-sh-P2Y4R-tranduced astrocytes (Fig. 5c).

\section{Knockdown of P2Y4R represses inflammation and neuron} death of hippocampal CA1 region in Tat-treated mice To further verify the role of P2Y4R in Tat-induced inflammatory process and neuron injury in vivo, IFA was performed to detect whether Tat induce P2Y4R protein level in astrocytes in the brain. As shown in Fig. 6a, b, Tat upregulated the expression of P2Y4R protein in astrocytes. Then, we assessed the effect of P2Y4R blockade by systemic administration of LV-sh-P2Y4R and LV-sh-Ctrl on mice (Fig. 6c). As shown in Fig. 6d, Tat increased P2Y4R protein expression in hippocampal region, but it was suppressed by LV-sh-P2Y4R. The mRNA levels of Tnfo, Il-6, IP-10, and $M c p-1$ were increased in the hippocampal tissues from Tat-injected mice, and were decreased by LV-sh-P2Y4R compared with LV-sh-Ctrl (Fig. 6e). Apoptotic cells of hippocampal neuron were measured by TUNEL staining and cresyl violet staining, respectively. As shown in Fig. 6f, g, compared with the PBS group, numbers of TUNEL-positive cells were significantly increased in the Tat-treated group. Administration of LV-sh-P2Y4R before Tat injection significantly reduced TUNEL-positive cells, comparing with the LV-sh-Ctrl group. Cresyl violet staining displayed that normal CA1 neuronal cells showed round and palely stained nuclei, whereas Tat-induced dead cells showed pyknotic nuclei (Fig. 6h). Administration of LV-sh-P2Y4R significantly decreased neuronal degeneration, compared with LV-sh-Ctrl group (Fig. 6h). Meantime, the neuronal density was dramatically decreased in Tat-treated mice, compared to PBS group; which was

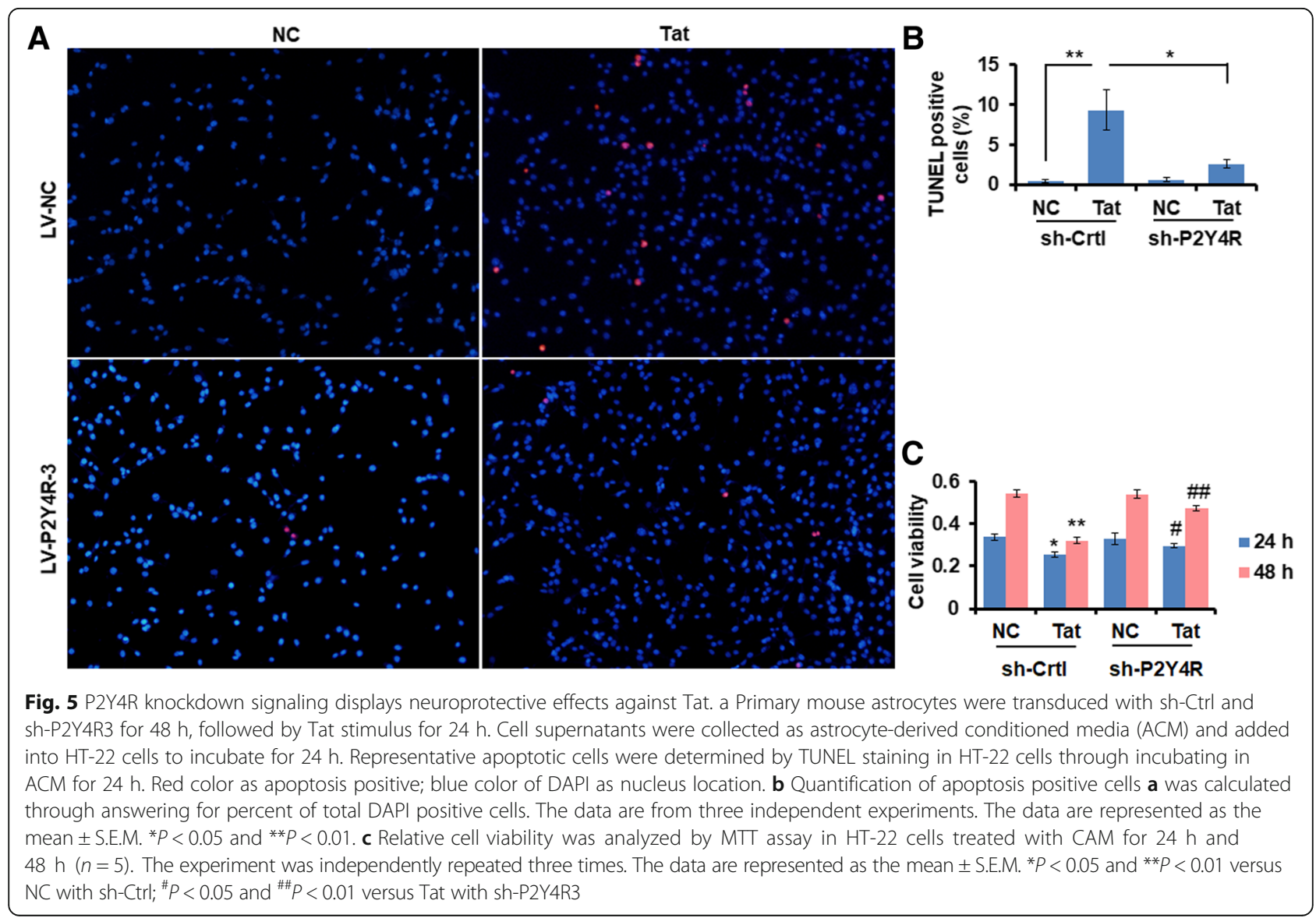




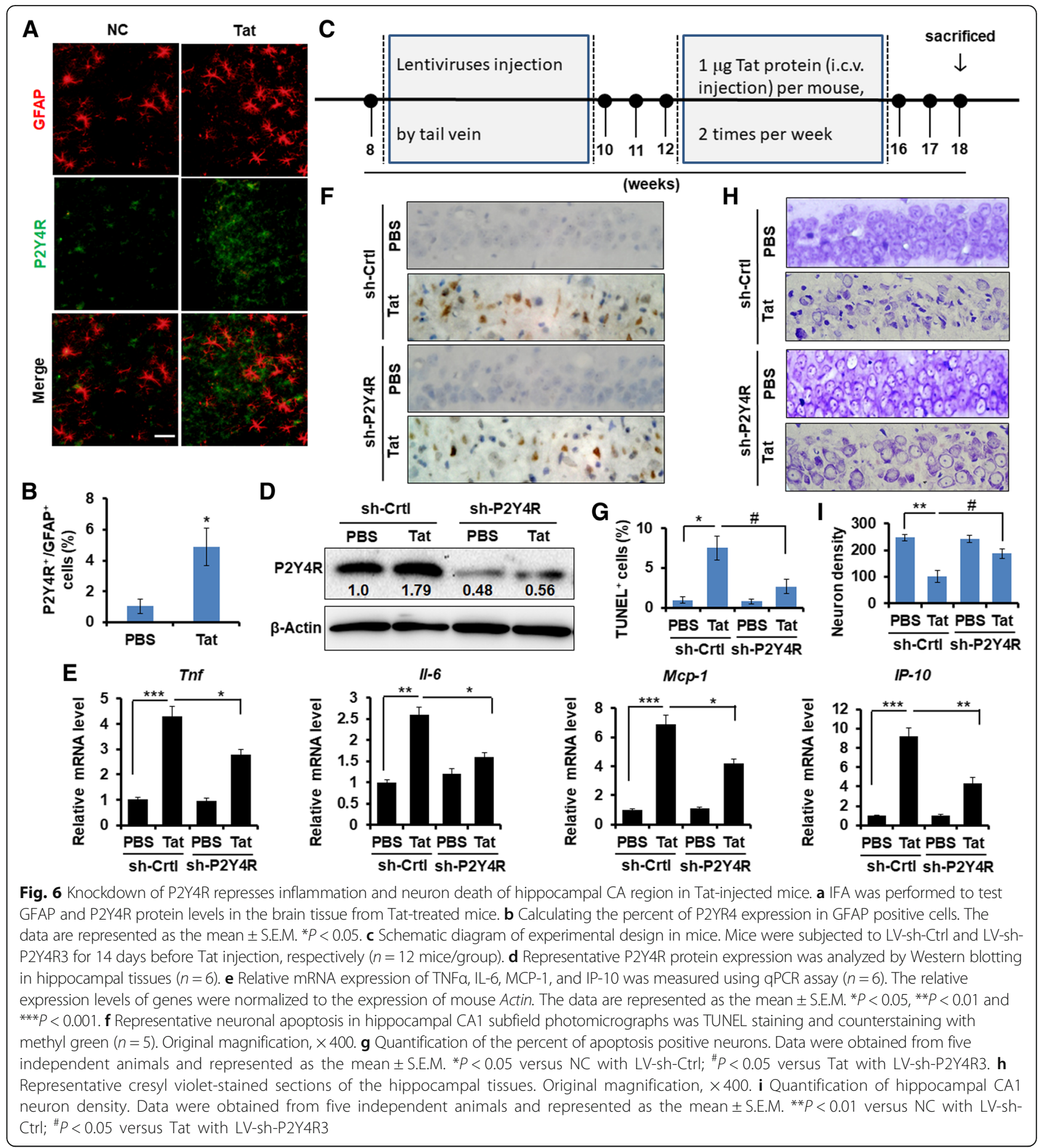

increased in LV-sh-P2Y4Rgroup, comparing with LV-sh-Ctrl group (Fig. 6i). Taken together, these results represent that inhibition of $\mathrm{P} 2 \mathrm{Y} 4 \mathrm{R}$ protects neuron death against Tat.

\section{Discussion}

A large body of evidence has demonstrated that purinergic P2 receptors play an important role in neuroinflammatory diseases such as Alzheimer's and Parkinson's diseases [53, 54]. Growing evidence shows that that P2X7 receptor activation induces large-scale ATP release. ATP acting via $\mathrm{P} 2 \mathrm{X} 7$ receptor is the second signal to the inflammasome activation, inducing both maturation and release of pro-inflammatory cytokines, such as IL-1 $\beta$ and IL-18, and the production of reactive nitrogen and oxygen species. Furthermore, the P2X7 receptor is involved in caspases 
activation, as well as in apoptosis induction [55]. Previous studies reported that Tat enhanced P2X7R expression to mediate neuroinflammation and neuronal damage [56]. However, few studies reported purinergic P2Y receptors on regulating inflammatory process and neuron injury in HAND. In the present study, we aimed to explore the role of purinergic P2Y receptors in regulating astrocytes functions and HAND pathogenesis. Here, we illustrated the effects of P2Y4R on the production of inflammatory cytokines in astrocytes with Tat treatment and neuron death (Fig. 7). Tat augmented P2Y4R expression through activated PI3K/Akt and ERK MAPK pathways to promote production of inflammatory cytokines and ATP. Notably, P2Y4R knockdown reduced inflammation and alleviated hippocampal neuron impairment in Tat-injected mice.

Numerous studies have determined that Tat is a vital neurotoxic mediator [30, 57]. Previous studies exhibited that soluble Tat protein triggers the production of proinflammatory chemokines like IL-8, IP-10, and MCP-1 [8, $25,56,57]$, as well as cytokines including IL-1 $\beta$, IL-6, and TNF- $\alpha$ in astrocytes $[26,56]$. Tat leads to endoplasmic reticulum (ER) stress in astrocytes, which in turn contributes to astrocyte-mediated Tat neurotoxicity [58]. In addition, Tat regulates excitatory amino acids and ATP, resulting in neuron cell death [28, 29]. However, the mechanism by which Tat promotes the production of inflammatory cytokines and ATP in astrocytes and HAND pathogenesis was not completely understood.

PI3K/Akt and ERK MAPK pathways play vital roles in cell growth and differentiation, metabolism, inflammation, and neurodegenerative diseases. In CNS, PI3K/Akt and ERK pathways are activated by ATP or UTP to regulate P2Y4R expression in astrocytes [41, 43]. Furthermore, activation of P2Y4R signaling can promote proinflammatory cytokines production and ATP release [59], in turn triggers calcium overload to exacerbate neuron apoptosis and dysfunction [31, 32, 60]. Here, we demonstrated that the expression of P2Y4R was significantly increased in astrocytes treated with soluble Tat, and suppressed by inhibition of PI3K/Akt and ERK pathways. Meanwhile, Tat increased ATP level via PI3K/Akt and ERK pathways. Of importance, extracellular ATP enhanced Tat-induced production of inflammatory cytokines and chemokines, indicating ATP promoting the productions of inflammatory cytokines through upregulating PI3K/Akt and ERK signals in astrocytes. We also found that reduction of P2Y4R expression by LV-shRNA significantly downregulated inflammatory cytokine expression in hippocampal tissues from Tat-injected mice. It was shown that modulating P2Y4R expression and PI3K/Akt and ERK signal activation would be a potential target for drug development aimed to control neuroinflammation and several types of inflammatory diseases $[25,38,41,59]$.

Inflammation of the CNS is a typical feature of neurological disorders that are characterized by activation of glial cells. In present study, we evaluated that $100 \mathrm{ng} / \mathrm{ml}$ of soluble Tat protein significantly triggered inflammatory cytokine production in astrocytes, and administration of $1 \mu \mathrm{g}$ Tat protein through i.c.v. infusion elicited inflammatory response in mice, which was decreased by P2Y4R knockdown. Notably, P2Y4R knockdown attenuated neuronal apoptosis and death through activated astrocytes by Tat in vitro, protected neuronal apoptosis against Tat, and restored hippocampal CA1 neuron density in vivo.

\section{Conclusion}

Taken together, our data demonstrated that the upregulation of P2Y4R signal both in mice and in activated

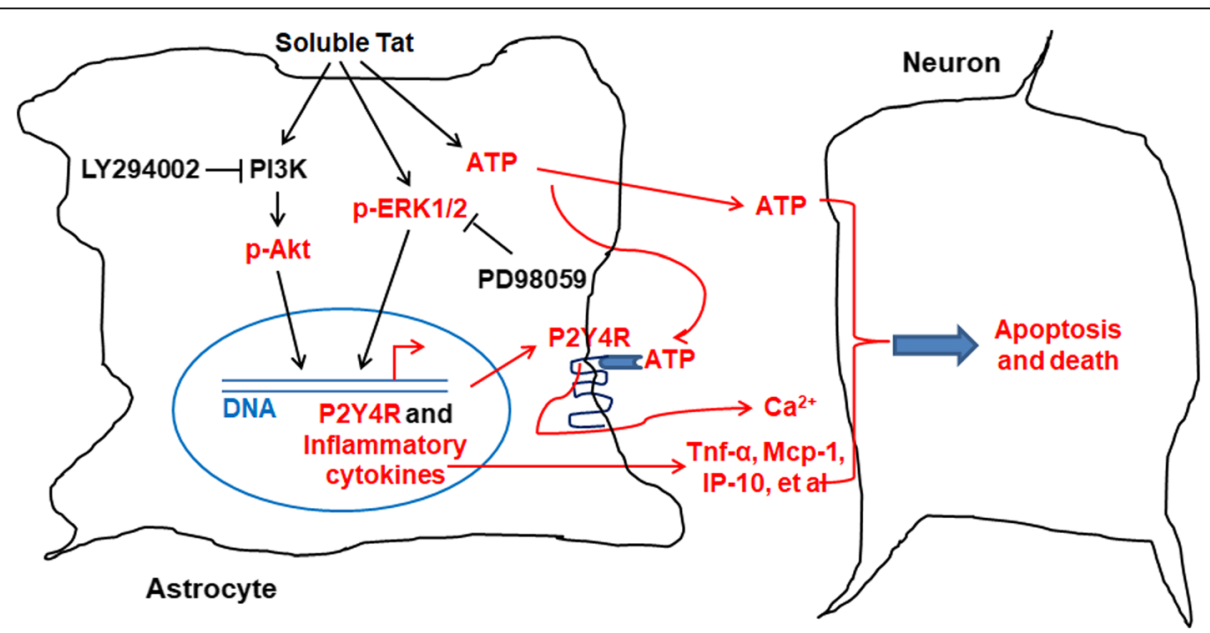

Fig. 7 Schematic diagram of P2Y4R signal activated by Tat via PI3K/Akt and ERK pathways in astrocyte-mediated neuron death. Under soluble Tat stimulation, P2Y4R are upregulated in astrocytes via PI3K/Akt and ERK pathways, which increases inflammatory process and ATP release to damage neuron, thus exacerbating the HAND process 
human astrocytes by Tat regulates the production of inflammatory cytokines and chemokines as well as ATP in astrocytes and in mice via triggering the PI3K/Akt and ERK pathways, which is responsible for HAND process. Thus, our findings on the underlying mechanisms that regulate astrocyte function and the HAND pathophysiological process broaden horizons in understanding of HAND pathophysiology and potential therapeutic strategies.

\section{Additional file}

Additional file 1: Figure S1. Distribution of GFP in CNS of mice infected by lentivirus. The lentivirus suspension of LV-sh-P2Y4R was injected into mice through the tail vein for 14 days, and then mice were sacrificed and frozen sections $(15 \mu \mathrm{m})$ from brain tissues. GFP expression was detected under fluorescence microscope $(n=3$, original amplification, $\times 40$ ). Table S1. The list of primer sequences for QPCR assay. (ZIP $263 \mathrm{~kb}$ )

\section{Abbreviations}

AIDS: Acquired immunodeficiency syndrome; AKT: Protein kinase B; BBB: Blood-brain barrier; CNS: The central nervous system; ERK1/ 2: Extracellular signal-regulated kinases 1 and 2; GFAP: Glial fibrillary acidic protein; HAART: Highly active antiretroviral therapy; HAD: HIV-associated dementia; HAND: HIV-associated neurocognitive disorder; HIV-1: Human immunodeficiency virus type 1; IL-1 $\beta$ : Interleukin-1 beta; IL-6: Interleukin-6; IP10: Interferon-gamma-inducible 10-Kd protein; MCP-1: Monocyte chemoattractant protein-1; NF-KB: Nuclear factor-kappa B; P2Y4R: Purinergic P2Y4 receptor; PI3K: Phosphoinosmde-3-kinase; Tat: Transactivator of transcription; TNF: Tumor necrosis factor

\section{Acknowledgements}

We thank that his work was supported by the Qing Lan Project.

\section{Funding}

This work was supported by Jiangsu Provincial Natural Science Foundation of China (BK20141136 to Zhou and BK20151168 to Liu), the National Natural Science Foundation of China (81500914 to Xue; 81372598 and 81772688 to $\mathrm{Gao}$ and 81700794 to $\mathrm{Hu}$ ), the Graduate Innovation Program in Science and Technology of Jiangsu Province (KYLX18_2169 to Cao), and the Priority Academic Program Development of Jiangsu Higher Education Institutions (2018 PAPD).

\section{Availability of data and materials}

All data generated or analyzed during this study are included in this published article and its supplementary information files.

\section{Authors' contributions}

F. Zhou, X. Liu and D. Gao designed research; L. Niu, X. Zhou, Q. Cao, W. Wang, D. Zuo, L. Gao, and X. Li performed research; F. Zhou, X. Liu, L. Niu, X. Zhou, M. Hu, and M. Xue analyzed data; F. Zhou, X. Liu, Y. Yang, Y. Yu, Y. Izumiya, B. Lee, B. Choi, R. Tang, Y. Wang, K. Zheng, and D. Gao drafted, wrote, and revised the paper. All authors read and approved the final manuscript.

\section{Ethics approval and consent to participate}

The study was approved by the Ethical Committee for Xuzhou Medical University.

\section{Consent for publication}

Not applicable.

\section{Competing interests}

The authors declare that they have no competing interests.

\section{Publisher's note}

Springer Nature remains neutral with regard to jurisdictional claims in published maps and institutional affiliations.

\section{Author details}

${ }^{1}$ Jiangsu Key Laboratory of Brain Disease Bioinformation, Research Center for Biochemistry and Molecular Biology, Xuzhou Medical University, Xuzhou, Jiangsu 221004, People's Republic of China. ${ }^{2}$ Jiangsu Key Laboratory of Immunity and Metabolism and Department of Pathogen Biology and Immunology, Xuzhou Medical University, 209 Tongshan Road, Xuzhou 221004, Jiangsu, China. ${ }^{3}$ Xuzhou Key Laboratory of Neurobiology, Department of Neurobiology and Anatomy, Xuzhou Medical University, Xuzhou 221004, Jiangsu, China. ${ }^{4}$ Department of Chemical and Biological Engineering, Hanbat National University, Dongseodaero 125, Yuseong-gu, Daejeon 305-719, South Korea. ${ }^{5}$ Department of Dermatology, University of California Davis (UC Davis) School of Medicine, Sacramento, CA, USA. ${ }^{6}$ Department of Physiology, Xuzhou Medical University, Xuzhou 221004, Jiangsu, China.

Received: 18 December 2018 Accepted: 26 March 2019

Published online: 04 April 2019

\section{References}

1. Clifford DB, Ances BM. HIV-associated neurocognitive disorder. Lancet Infect Dis. 2013;13(11):976-86.

2. Ghafouri M, Amini S, Khalili K, Sawaya BE. HIV-1 associated dementia: symptoms and causes. Retrovirology. 2006;3:28.

3. Spudich S. HIV and neurocognitive dysfunction. Curr HIV/AIDS Rep. 2013; 10(3):235-43.

4. Matinella A, Lanzafame M, Bonometti MA, Gajofatto A, Concia E, Vento S, Monaco S, Ferrari S. Neurological complications of HIV infection in preHAART and HAART era: a retrospective study. J Neurol. 2015;262(5):1317-27.

5. Hong S, Banks WA. Role of the immune system in HIV-associated neuroinflammation and neurocognitive implications. Brain Behav Immun. 2015;45:1-12.

6. Gaskill PJ, Miller DR, Gamble-George J, Yano H, Khoshbouei HHIV. Tat and dopamine transmission. Neurobiol Dis. 2017:10551-73.

7. Huang Y, Zhao L, Jia B, Wu L, Li Y, Curthoys N, Zheng JC. Glutaminase dysregulation in HIV-1-infected human microglia mediates neurotoxicity: relevant to HIV-1-associated neurocognitive disorders. J Neurosci. 2011; 31(42):15195-204.

8. Youn GS, Ju SM, Choi SY, Park J. HDAC6 mediates HIV-1 tat-induced proinflammatory responses by regulating MAPK-NF-kappaB/AP-1 pathways in astrocytes. Glia. 2015:63(11):1953-65.

9. Minagar A, Shapshak P, Fujimura R, Ownby R, Heyes M, Eisdorfer C. The role of macrophage/microglia and astrocytes in the pathogenesis of three neurologic disorders: HIV-associated dementia, Alzheimer disease, and multiple sclerosis. J Neurol Sci. 2002;202(1-2):13-23.

10. Budka H, Wiley CA, Kleihues P, Artigas J, Asbury AK, Cho ES, Cornblath DR, Dal Canto MC, DeGirolami U, Dickson D, et al. HIV-associated disease of the nervous system: review of nomenclature and proposal for neuropathologybased terminology. Brain Pathol. 1991;1(3):143-52.

11. Allen NJ, Barres BA. NEUROSCIENCE glia-more than just brain glue. Nature. 2009:457(7230):675-7.

12. Barres BA. The mystery and magic of glia: a perspective on their roles in health and disease. Neuron. 2008;60(3):430-40.

13. Williams R, Dhillon NK, Hegde ST, Yao H, Peng F, Callen S, Chebloune Y, Davis RL, Buch SJ. Proinflammatory cytokines and HIV-1 synergistically enhance CXCL10 expression in human astrocytes. Glia. 2009:57(7):734-43.

14. Peng H, Erdmann N, Whitney N, Dou H, Gorantla S, Gendelman HE, Ghorpade A, Zheng J. HIV-1-infected and/or immune activated macrophages regulate astrocyte SDF-1 production through IL-1 beta. Glia. 2006;54(6):619-29.

15. Wilson EH, Weninger W, Hunter CA. Trafficking of immune cells in the central nervous system. J Clin Invest. 2010;120(5):1368-79.

16. Bezzi P, Domerca M, Brambilla L, Galli R, Schols D, De Clerca E, Vescovi A, Bagetta G, Kollias G, Meldolesi J, Volterra A. CXCR4-activated astrocyte glutamate release via TNFalpha: amplification by microglia triggers neurotoxicity. Nat Neurosci. 2001;4(7):702-10.

17. Graziano F, Desdouits M, Garzetti L, Podini P, Alfano M, Rubartelli A, Furlan R, Benaroch P, Poli G. Extracellular ATP induces the rapid release of HIV-1 
from virus containing compartments of human macrophages. Proc Natl Acad Sci U S A. 2015;112(25):E3265-73.

18. Johnson TP, Patel K, Johnson KR, Maric D, Calabresi PA, Hasbun R, Nath A. Induction of IL-17 and nonclassical T-cell activation by HIV-Tat protein. Proc Natl Acad Sci U S A. 2013;110(33):13588-93.

19. Gonek M, McLane VD, Stevens DL, Lippold K, Akbarali HI, Knapp PE, Dewey WL, Hauser KF, Paris JJ. CCR5 mediates HIV-1 Tat-induced neuroinflammation and influences morphine tolerance, dependence, and reward. Brain Behav Immun. 2018;69124:38.

20. Bonwetsch R, Croul S, Richardson MW, Lorenzana C, Del Valle L, Sverstiuk AE, Amini S, Morgello S, Khalili K, Rappaport J. Role of HIV-1 Tat and CC chemokine MIP-1alpha in the pathogenesis of HIV associated central nervous system disorders. J Neuro-Oncol. 1999;5(6):685-94.

21. Bagashev A, Sawaya BE. Roles and functions of HIV-1 Tat protein in the CNS: an overview. Virol J. 2013;10:358.

22. Niu F, Yao H, Zhang W, Sutliff RL, Buch S. Tat 101-mediated enhancement of brain pericyte migration involves platelet-derived growth factor subunit B homodimer: implications for human immunodeficiency virus-associated neurocognitive disorders. J Neurosci. 2014;34(35):11812-25.

23. Fields JA, Dumaop W, Crews L, Adame A, Spencer B, Metcalf J, He J, Rockenstein E, Masliah E. Mechanisms of HIV-1 Tat neurotoxicity via CDK5 translocation and hyper-activation: role in HIV-associated neurocognitive disorders. Curr HIV Res. 2015;13(1):43-54.

24. Henderson L, Sharma A, Monaco MC, Major EO, Al-Harthi L. Human immunodeficiency virus type 1 (HIV-1) transactivator of transcription through its intact core and cysteine-rich domains inhibits Wnt/beta-catenin signaling in astrocytes: relevance to HIV neuropathogenesis. J Neurosci. 2012;32(46):16306-13.

25. Nookala AR, Shah A, Noel RJ, Kumar A. HIV-1 Tat-mediated induction of CCL5 in astrocytes involves NF-kappaB, AP-1, C/EBPalpha and C/EBPgamma transcription factors and JAK, PI3K/Akt and p38 MAPK signaling pathways. PLoS One. 2013:8(11):e78855.

26. Nookala AR, Kumar A. Molecular mechanisms involved in HIV-1 Tatmediated induction of IL-6 and IL-8 in astrocytes. J Neuroinflammation. 2014;11:214

27. Dhillon N, Zhu XH, Peng FW, Yao HH, Williams R, Callen S, Ladner AO, Buch $\mathrm{S}$, Qiu JM. Molecular mechanism(s) involved in the synergistic induction of CXCL10 by human immunodeficiency virus type 1 Tat and interferongamma in macrophages. J Neuro-Oncol. 2008;14(3):196-204.

28. Stevens PR, Gawryluk JW, Hui L, Chen XS, Geiger JD. Creatine protects against mitochondrial dysfunction associated with HIV-1 Tat-induced neuronal injury. Curr HIV Res. 2014;12(6):378-87.

29. Kruman II, Nath A, Mattson MP. HIV-1 protein Tat induces apoptosis of hippocampal neurons by a mechanism involving caspase activation, calcium overload, and oxidative stress. Exp Neurol. 1998;154(2):276-88.

30. Raybuck JD, Hargus NJ, Thayer SA. A GluN2B-selective NMDAR antagonist reverses synapse loss and cognitive impairment produced by the HIV-1 protein tat. J Neurosci. 2017;37(33):7837-47.

31. Del Puerto A, Wandosell F, Garrido JJ. Neuronal and glial purinergic receptors functions in neuron development and brain disease. Front Cell Neurosci. 2013;7:197.

32. Fischer W, Appelt K, Grohmann M, Franke H, Norenberg W, Illes P. Increase of intracellular Ca2+ by P2X and P2Y receptor-subtypes in cultured cortical astroglia of the rat. Neuroscience. 2009;160(4):767-83.

33. Burnstock G, Krugel U, Abbracchio MP, Illes P. Purinergic signalling: from normal behaviour to pathological brain function. Prog Neurobiol. 2011;95(2): 229-74

34. Koles $L$, Leichsenring A, Rubini P, Illes P. P2 receptor signaling in neurons and glial cells of the central nervous system. Adv Pharmacol. 2011:61:441-93.

35. Jacobson KA, Balasubramanian R, Deflorian F, Gao ZG. G protein-coupled adenosine (P1) and $\mathrm{P} 2 \mathrm{Y}$ receptors: ligand design and receptor interactions. Purinergic Signal. 2012;8(3):419-36.

36. Lammer A, Gunther A, Beck A, Krugel U, Kittner H, Schneider D, Illes $P$, Franke $H$. Neuroprotective effects of the P2 receptor antagonist PPADS on focal cerebral ischaemia-induced injury in rats. Eur J Neurosci. 2006;23(10): 2824-8

37. Zheng W, Watts LT, Holstein DM, Prajapati SI, Keller C, Grass EH, Walter CA Lechleiter JD. Purinergic receptor stimulation reduces cytotoxic edema and brain infarcts in mouse induced by photothrombosis by energizing glial mitochondria. PLoS One. 2010;5(12):e14401.
38. Kuboyama K, Harada H, Tozaki-Saitoh H, Tsuda M, Ushijima K, Inoue K. Astrocytic P2Y(1) receptor is involved in the regulation of cytokine/ chemokine transcription an cerebral damage in a rat model of cerebral ischemia. J Cereb Blood Flow Metab. 2011;31(9):1930-41.

39. Lin Y, Desbois A, Jiang S, Hou ST. P2 receptor antagonist PPADS confers neuroprotection against glutamate/NMDA toxicity. Neurosci Lett. 2005; 377(2):97-100

40. Qian $Y, X u$ S, Yang $X$, Xiao Q. Purinergic receptor P2Y6 contributes to 1methyl-4-phenylpyridinium-induced oxidative stress and cell death in neuronal SH-SY5Y cells. J Neurosci Res. 2018;96(2):253-64.

41. Franke H, Sauer C, Rudolph C, Krugel U, Hengstler JG, Illes P. P2 receptormediated stimulation of the PI3-K/Akt-pathway in vivo. Glia. 2009;57(10): 1031-45.

42. Neary JT, Kang Y, Shi YF, Tran MD, Wanner IB. P2 receptor signalling, proliferation of astrocytes, and expression of molecules involved in cell-cell interactions. Novartis Found Symp. 2006:276131-43 discussion 43-7, 233-7, 75-81.

43. Stevens B, Ishibashi T, Chen JF, Fields RD. Adenosine: an activity-dependent axonal signal regulating MAP kinase and proliferation in developing Schwann cells. Neuron Glia Biol. 2004;1(1):23-34.

44. Liu X, He F, Pang R, Zhao D, Qiu W, Shan K, Zhang J, Lu Y, Li Y, Wang Y. Interleukin-17 (IL-17)-induced microRNA 873 (miR-873) contributes to the pathogenesis of experimental autoimmune encephalomyelitis by targeting A20 ubiquitin-editing enzyme. J Biol Chem. 2014;289(42):28971-86.

45. Zhou F, Liu XM, Zuo DJ, Xue M, Gao L, Yang Y, Wang J, Niu LP, Cao QW, Li XY, et al. HIV-1 Nef-induced IncRNA AK006025 regulates CXCL9/10/11 cluster gene expression in astrocytes through interaction with CBP/P300. J Neuroinflammation. 2018;15(1):303.

46. Liu X, Zhou F, Yang Y, Wang W, Niu L, Zuo D, Li X, Hua H, Zhang B, Kou Y, et al. MiR-409-3p and MiR-1896 co-operatively participate in IL-17-induced inflammatory cytokine production in astrocytes and pathogenesis of EAE mice via targeting SOCS3/STAT3 signaling. Glia. 2019;67(1):101-112.

47. Liu X, Zhang Q, Wang W, Zuo D, Wang J, Zhou F, Niu L, Li X, Qin S, Kou Y, et al. Analysis of long noncoding RNA and mRNA expression profiles in IL-9activated astrocytes and EAE mice. Cell Physiol Biochem. 2018;45(5):1986-98.

48. Zhou F, Xue M, Qin D, Zhu X, Wang C, Zhu J, Hao T, Cheng L, Chen X, Bai $Z$, et al. HIV-1 Tat promotes Kaposi's sarcoma-associated herpesvirus (KSHV) VIL-6-induced angiogenesis and tumorigenesis by regulating PI3K/PTEN/ AKT/GSK-3beta signaling pathway. PLoS One. 2013;8(1):e53145.

49. Yao S, Hu M, Hao T, Li W, Xue X, Xue M, Zhu X, Zhou F, Qin D, Yan Q, et al. MiRNA-891a-5p mediates HIV-1 Tat and KSHV Orf-K1 synergistic induction of angiogenesis by activating NF-kappaB signaling. Nucleic Acids Res. 2015; 43(19):9362-78

50. Smyth LCD, Rustenhoven J, Park TI, Schweder P, Jansson D, Heppner PA, O'Carroll SJ, Mee EW, Faull RLM, Curtis M, Dragunow M. Unique and shared inflammatory profiles of human brain endothelia and pericytes. J Neuroinflammation. 2018:15(1):138.

51. Qiu W, Su M, Xie F, Ai J, Ren Y, Zhang J, Guan R, He W, Gong Y, Guo Y. Tetrandrine blocks autophagic flux and induces apoptosis via energetic impairment in cancer cells. Cell Death Dis. 2014;5:e1123.

52. Liu XM, Pei DS, Guan QH, Sun YF, Wang XT, Zhang QX, Zhang GY. Neuroprotection of Tat-GluR6-9c against neuronal death induced by kainate in rat hippocampus via nuclear and non-nuclear pathways. J Biol Chem. 2006;281(25):17432-45

53. Burnstock $\mathrm{G}$. An introduction to the roles of purinergic signalling in neurodegeneration, neuroprotection and neuroregeneration. Neuropharmacology. 2016:1044-17.

54. Oliveira A, Illes P, Ulrich H. Purinergic receptors in embryonic and adult neurogenesis. Neuropharmacology. 2016:104272-81.

55. Savio LEB, de Andrade Mello P, da Silva CG, Coutinho-Silva R. The P2X7 receptor in inflammatory diseases: angel or demon? Front Pharmacol. 2018;9:52.

56. Tewari M, Monika VRK, Menon M, Seth P. Astrocytes mediate HIV-1 Tatinduced neuronal damage via ligand-gated ion channel P2X7R. J Neurochem. 2015:132(4):464-76.

57. Fitting S, Zou S, El-Hage N, Suzuki M, Paris JJ, Schier CJ, Rodriguez JW, Rodriguez M, Knapp PE, Hauser KF. Opiate addiction therapies and HIV-1 Tat: interactive effects on glial $[\mathrm{Ca}(2)(+)] \mathrm{i}$, oxyradical and neuroinflammatory chemokine production and correlative neurotoxicity. Curr HIV Res. 2014; 12(6):424-34.

58. Fan Y, He J. HIV-1 Tat induces unfolded protein response and endoplasmic reticulum stress in astrocytes and causes neurotoxicity through glial fibrillary 
acidic protein (GFAP) activation and aggregation. J Biol Chem. 2016;291(43): 22819-29.

59. Rafehi M, Muller CE. Tools and drugs for uracil nucleotide-activated P2Y receptors. Pharmacol Ther. 2018;190:24-80.

60. Paris JJ, Zou S, Hahn YK, Knapp PE, Hauser KF. 5alpha-reduced progestogens ameliorate mood-related behavioral pathology, neurotoxicity, and microgliosis associated with exposure to HIV-1 Tat. Brain Behav Immun. 2016:55202-14.

Ready to submit your research? Choose BMC and benefit from:

- fast, convenient online submission

- thorough peer review by experienced researchers in your field

- rapid publication on acceptance

- support for research data, including large and complex data types

- gold Open Access which fosters wider collaboration and increased citations

- maximum visibility for your research: over $100 \mathrm{M}$ website views per year

At $B M C$, research is always in progress.

Learn more biomedcentral.com/submissions 